\title{
(2) อంญ)ఠอి
}

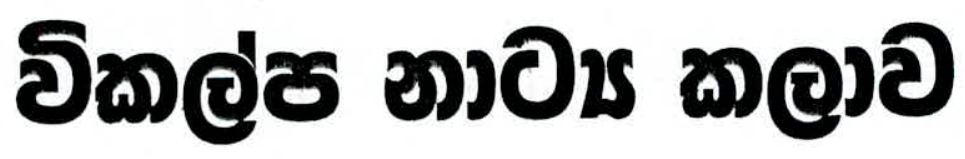

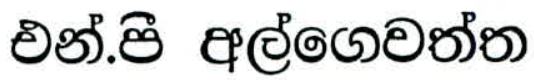




\section{(2) อంది)తరి}

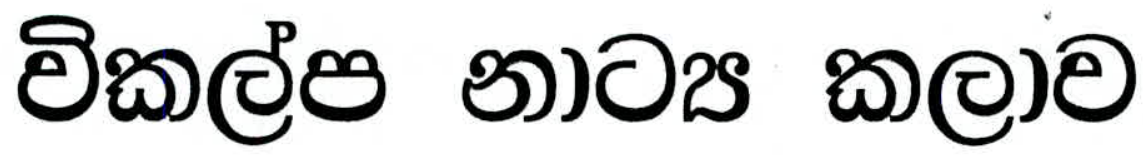

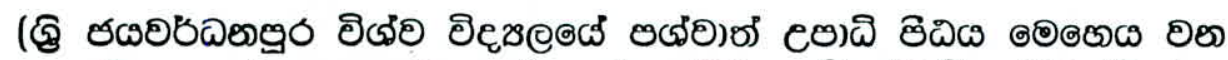

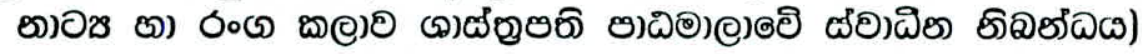

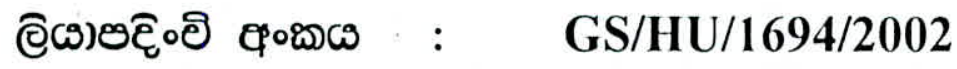

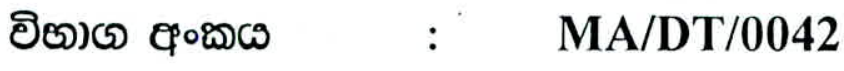

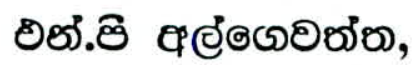

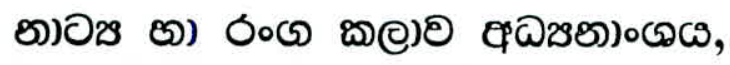

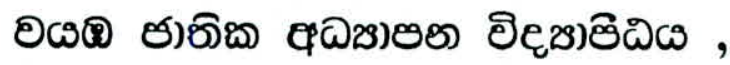
ఖింธిరิต . 
ฮิత్

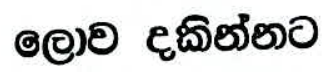

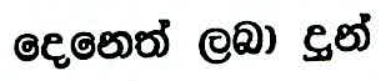

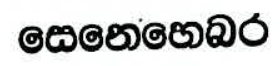

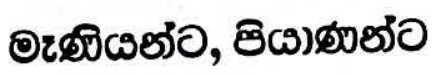

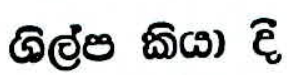

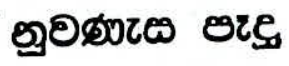

हृ(1)வல

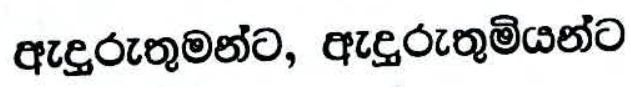

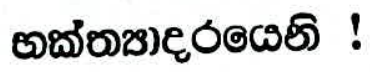




\section{ผீర్రీడ}

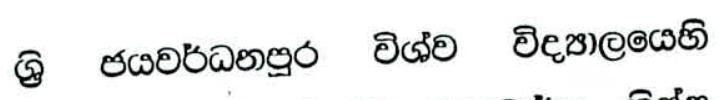

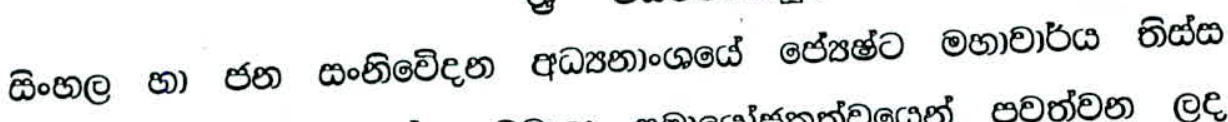

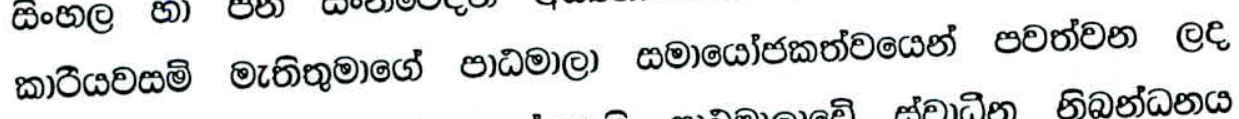

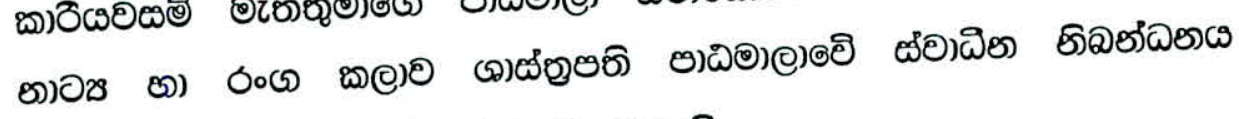

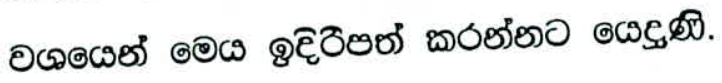

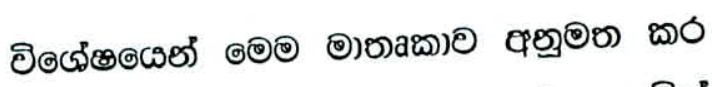

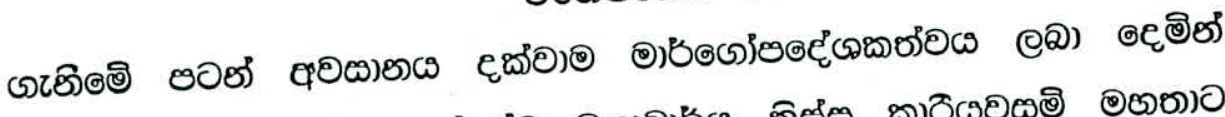

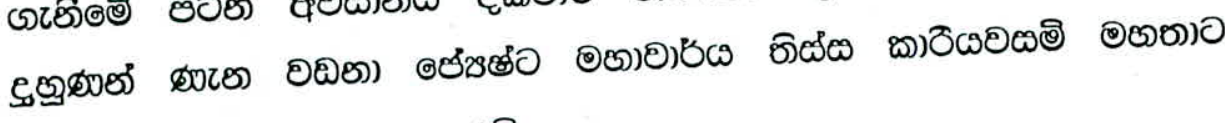

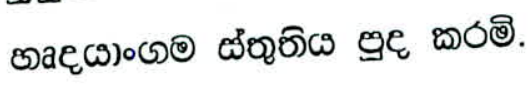

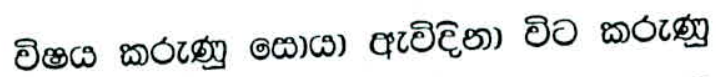

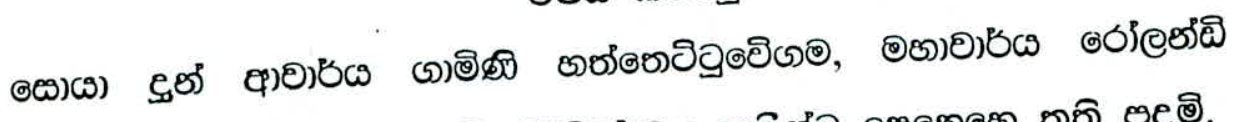

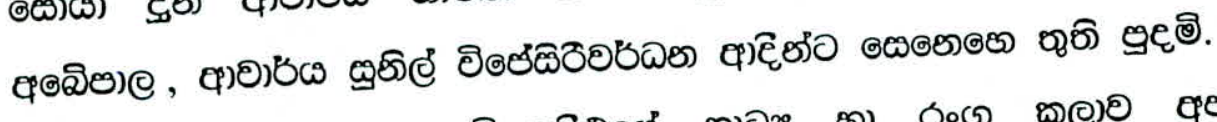

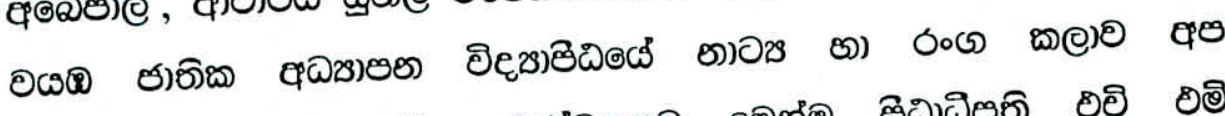

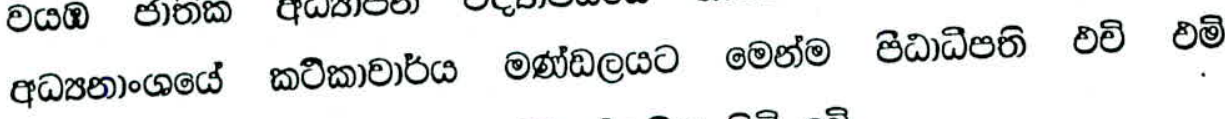

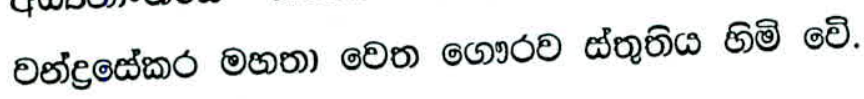

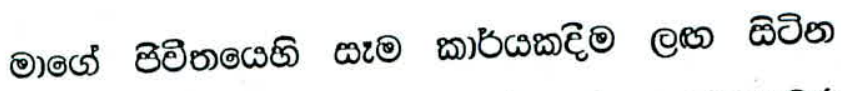

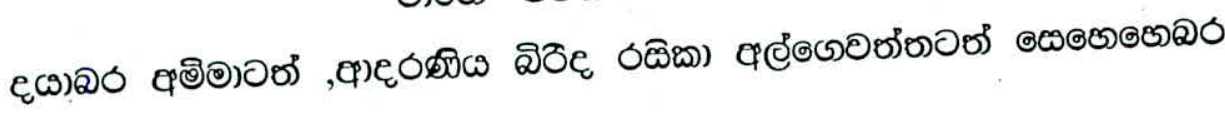

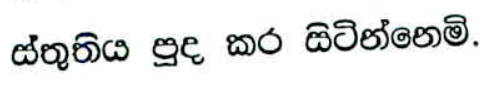




\section{ชిิి}

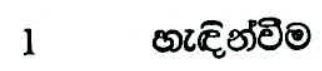

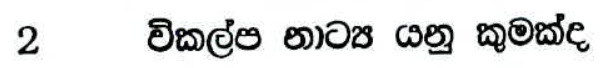

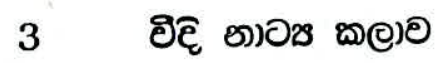

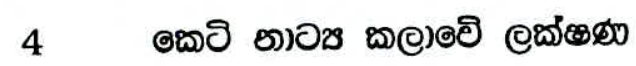

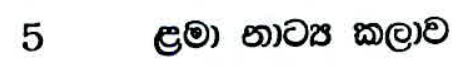

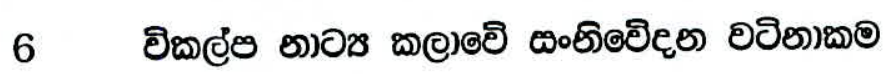

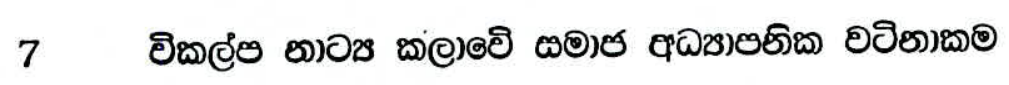

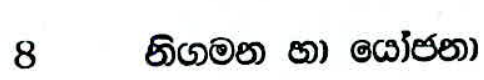

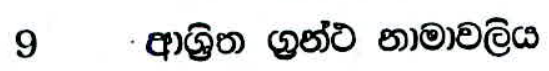

$$
1-3
$$$$
4-12
$$

$13-21$

$22-29$

$30-52$

$53-58$

$59-64$

$65-67$

$68-70$ 


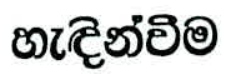

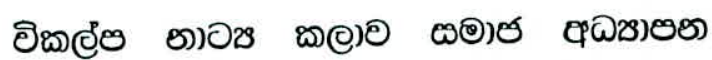

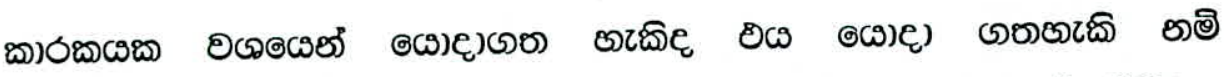

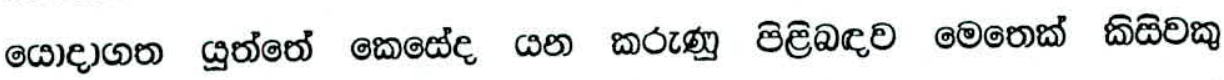

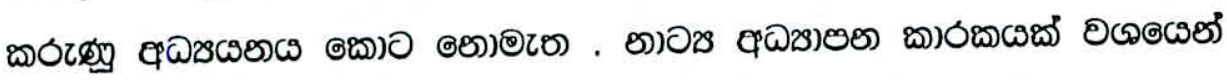

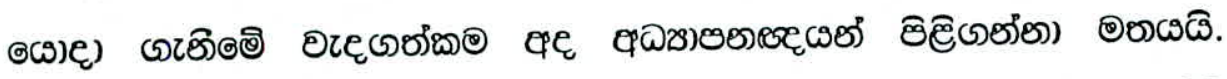

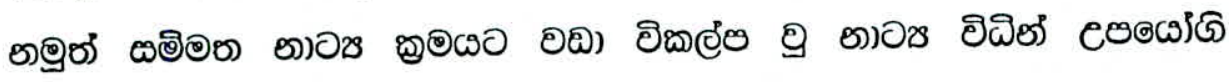

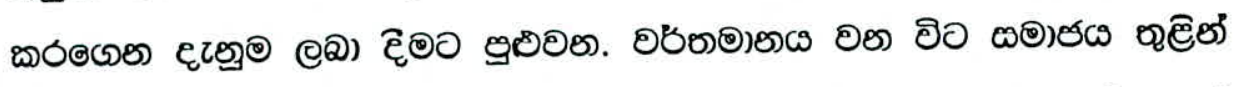

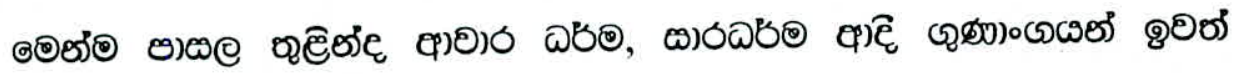

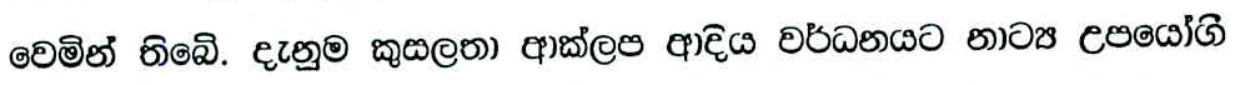

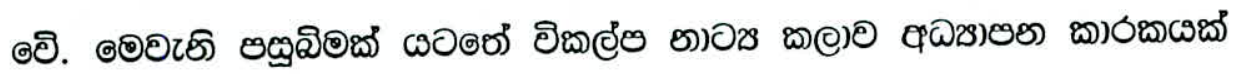

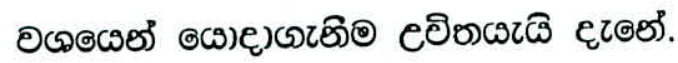

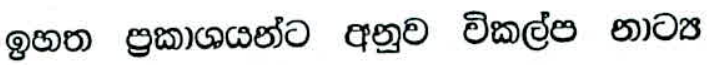

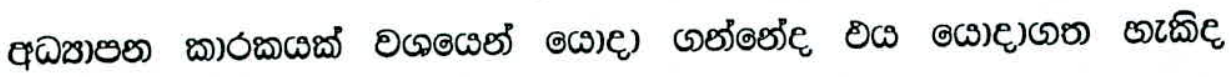

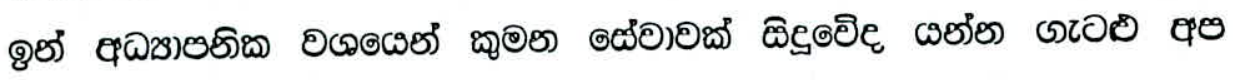

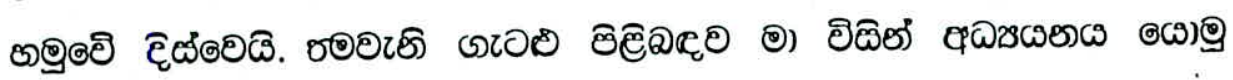
దురంீீఠితి.

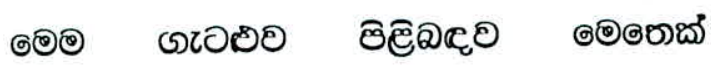

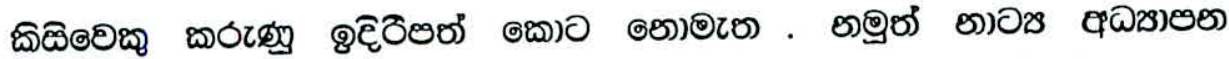

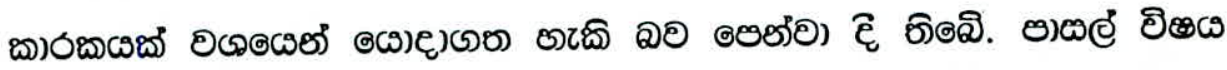

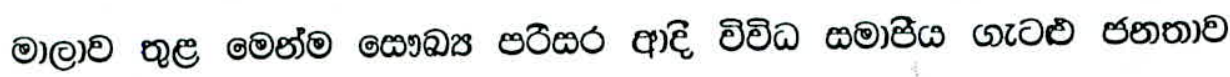

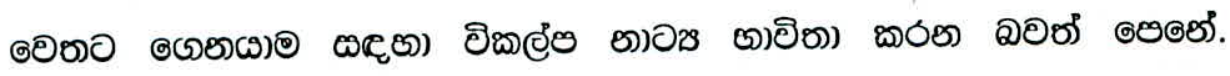

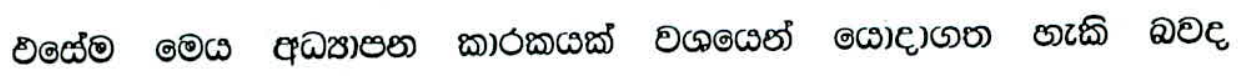

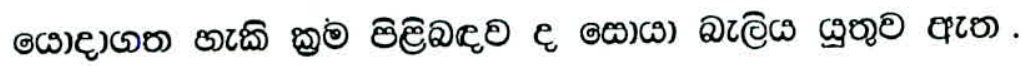




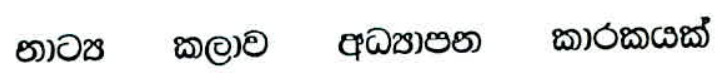

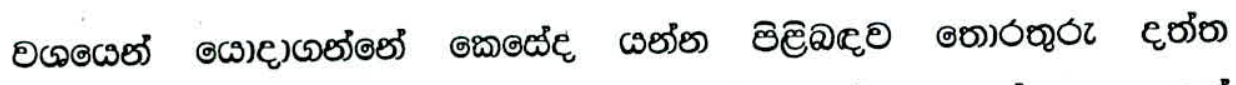

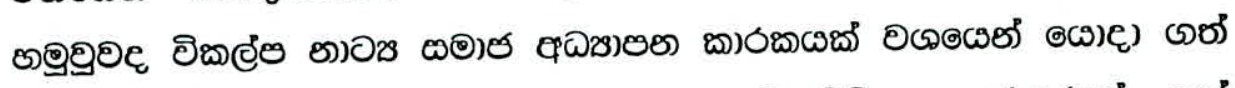

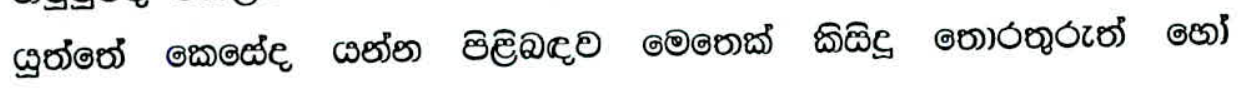

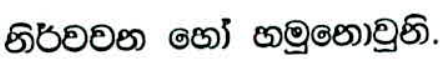

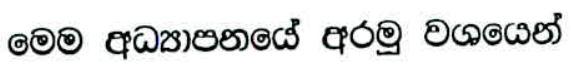

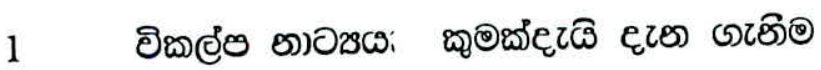

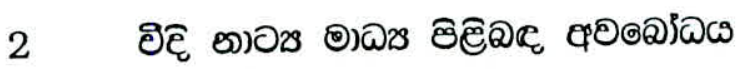

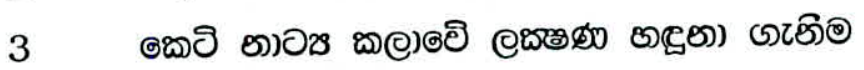

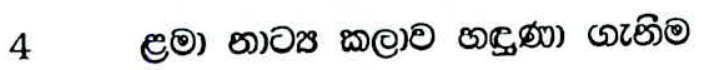

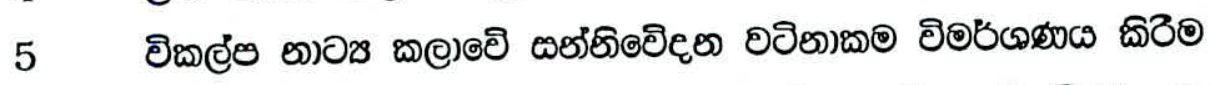

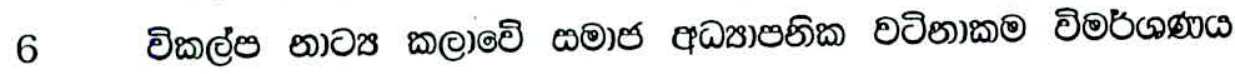
దิరెอ

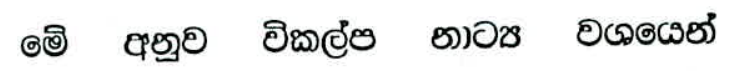

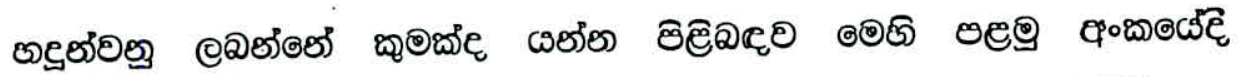

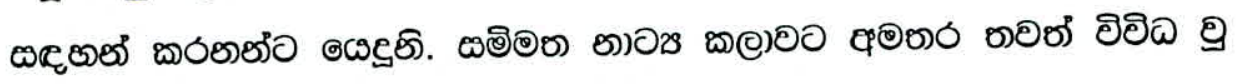

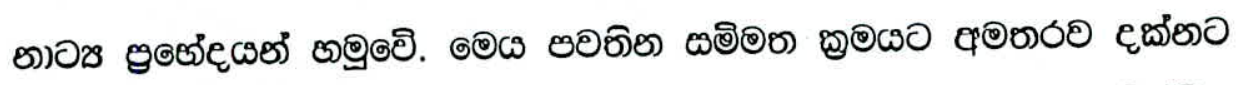

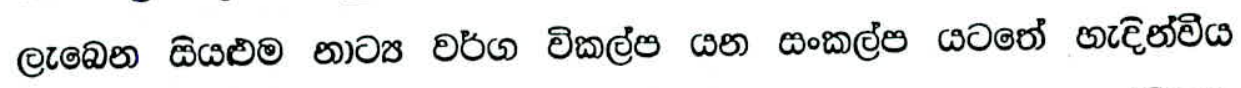

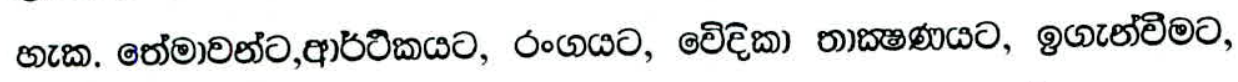

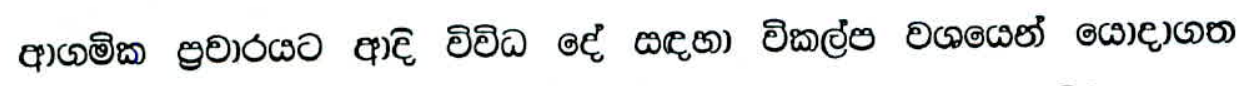

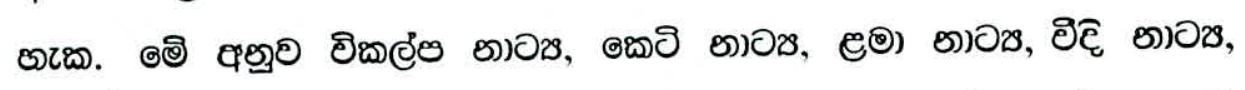

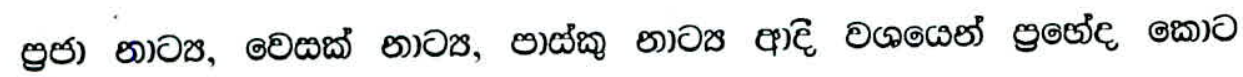

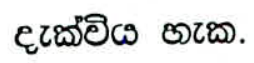

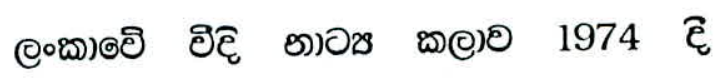

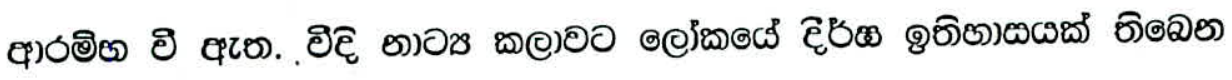

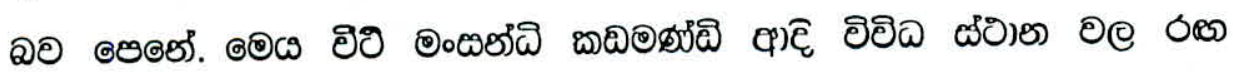




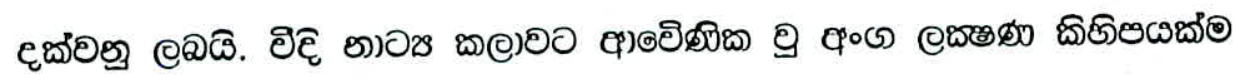

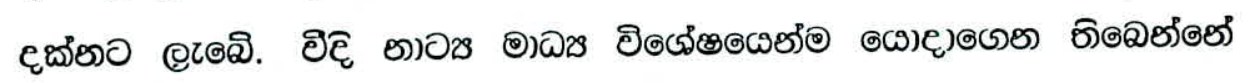

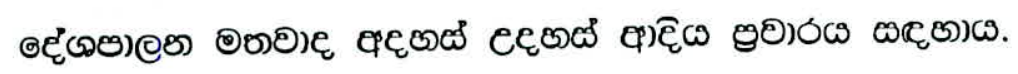

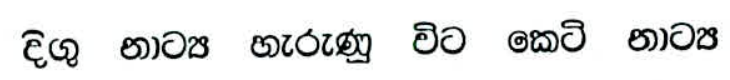

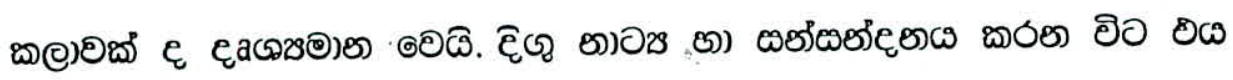

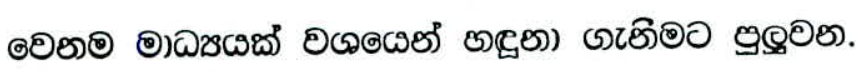

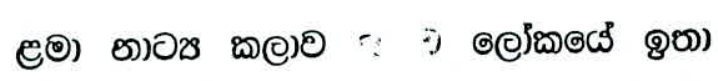

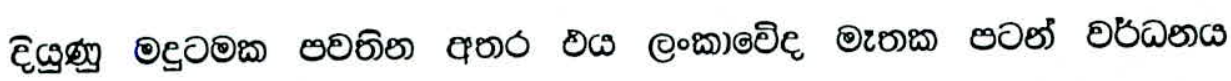

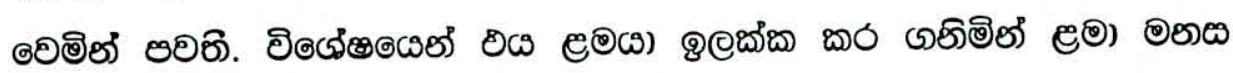

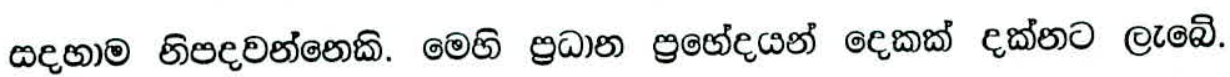

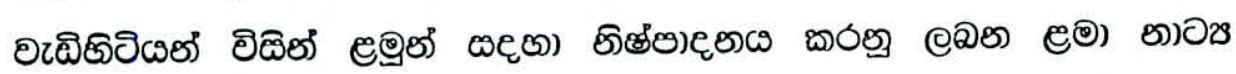

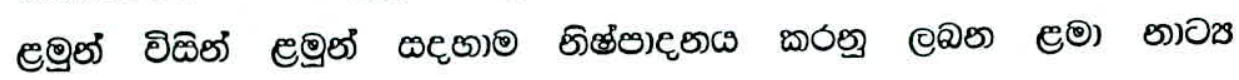
อஸ๐மిలీ.

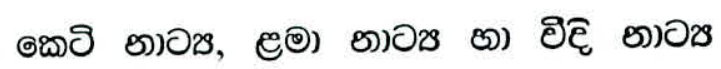

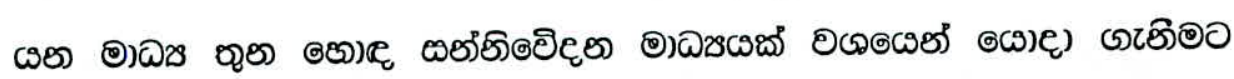

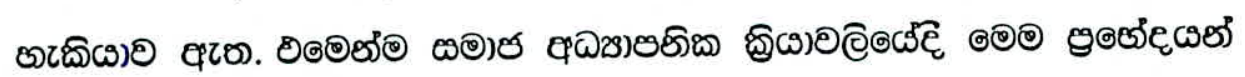

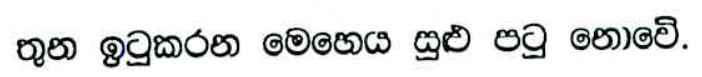

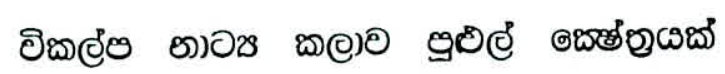

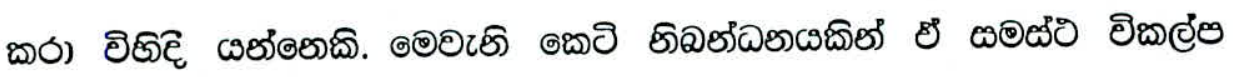

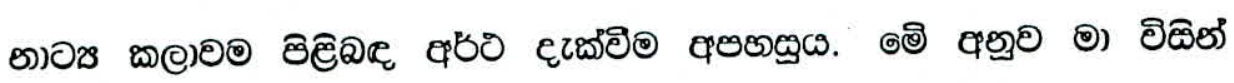

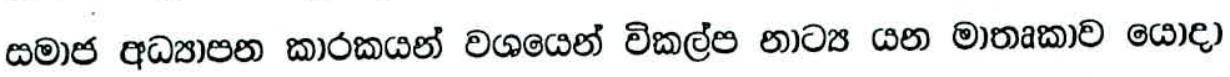

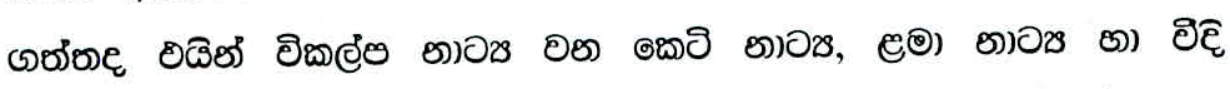

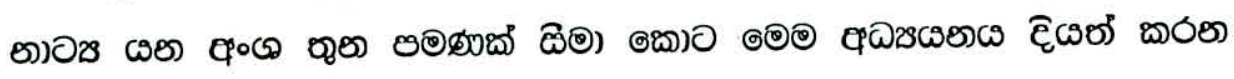
๑)ิ. 


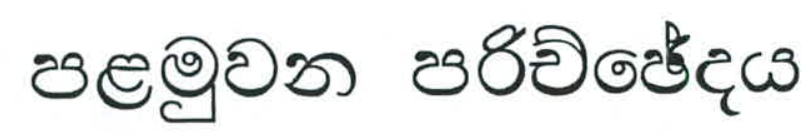




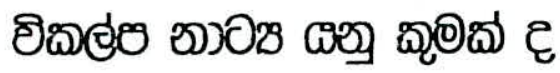

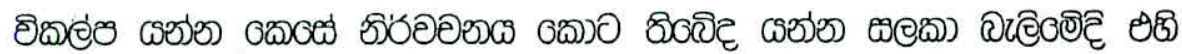

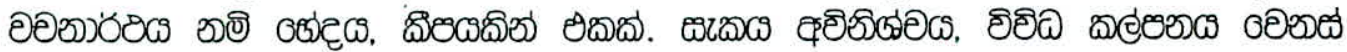

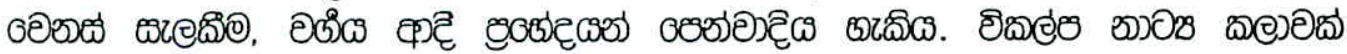

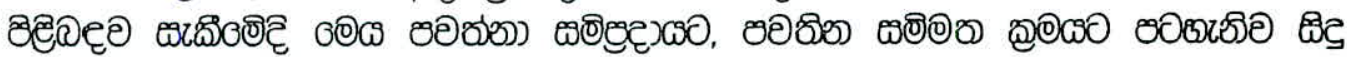

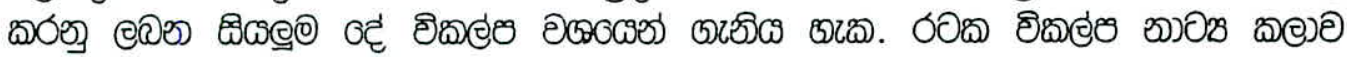

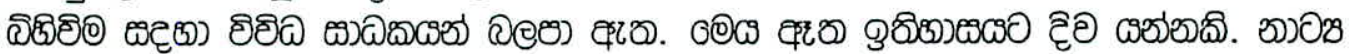

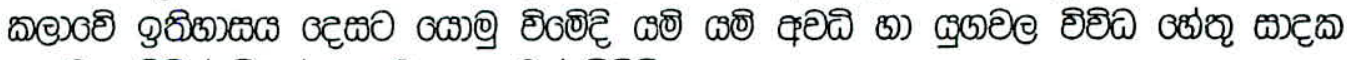

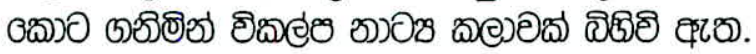

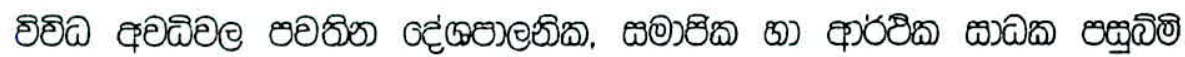

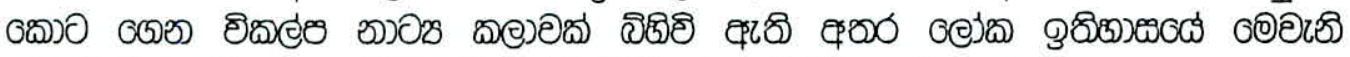

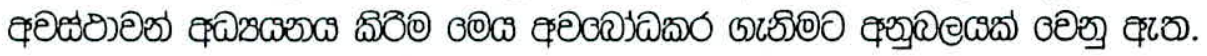

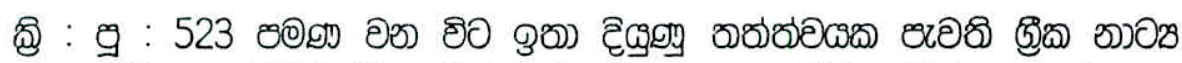

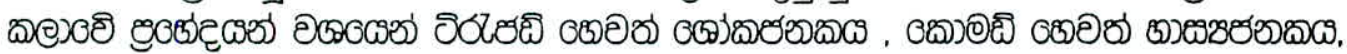

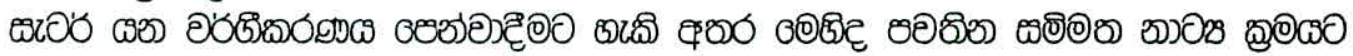

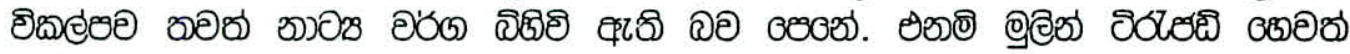

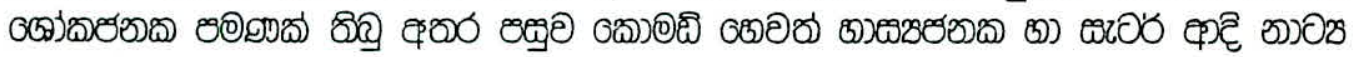

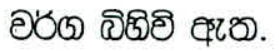

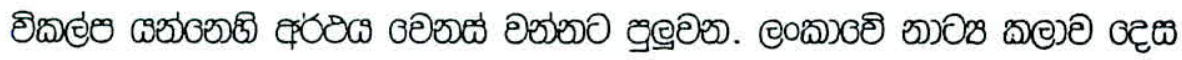

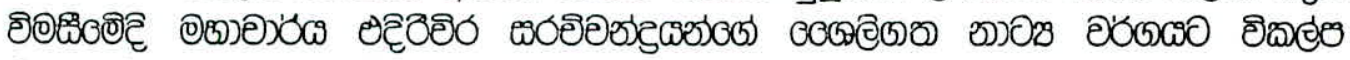

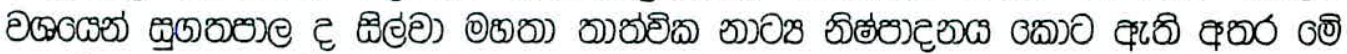

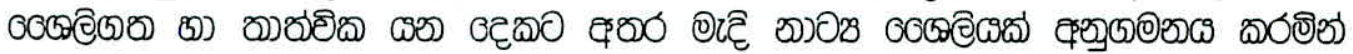

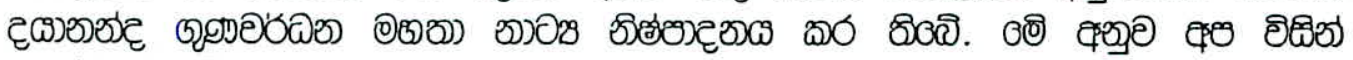

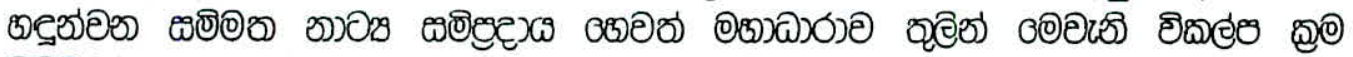

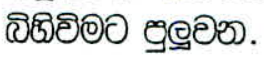

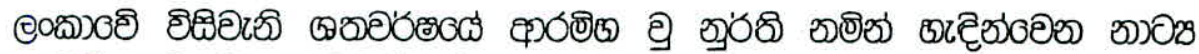

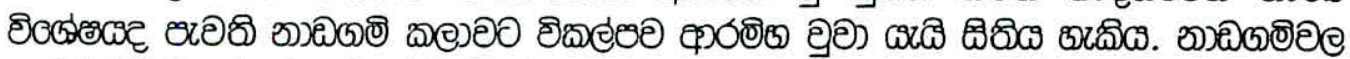

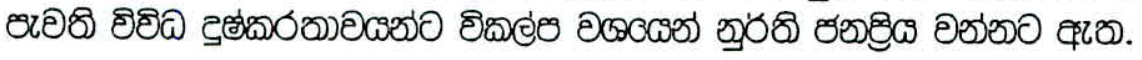

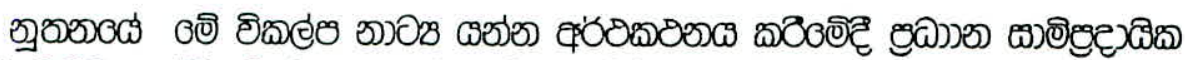

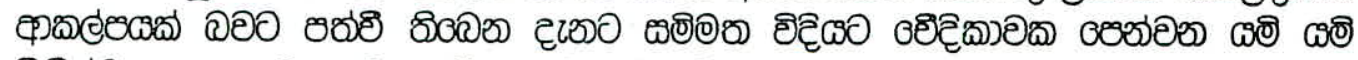

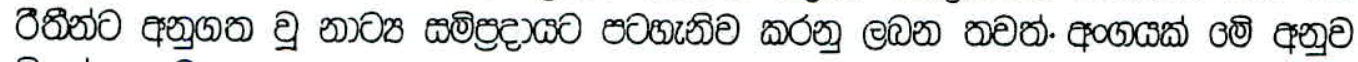

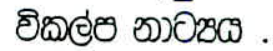

\begin{tabular}{|c|c|}
\hline$\%$ & 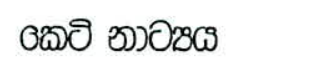 \\
\hline$*$ & 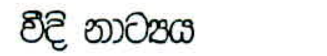 \\
\hline$\%$ & 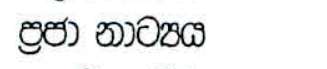 \\
\hline$\%$ & 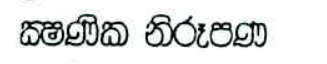 \\
\hline$*$ & 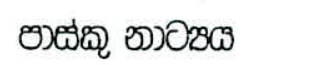 \\
\hline$*$ & 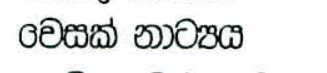 \\
\hline$\star$ & 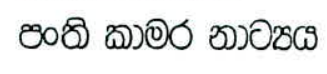 \\
\hline
\end{tabular}




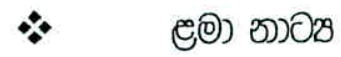

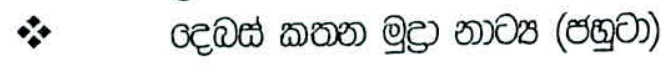

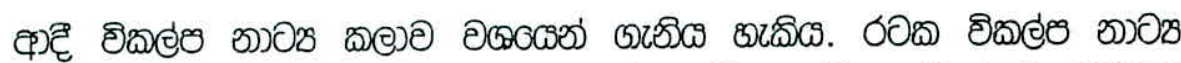

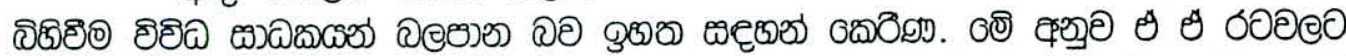

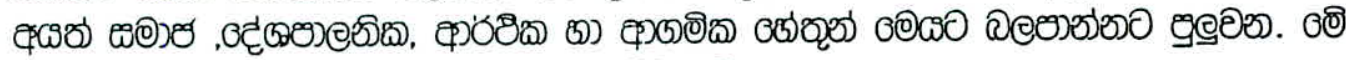

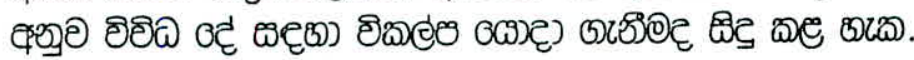

\begin{tabular}{|c|c|}
\hline$*$ & 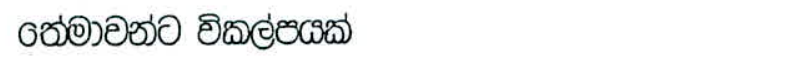 \\
\hline$*$ & 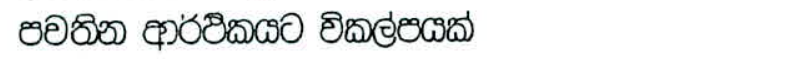 \\
\hline$*$ & 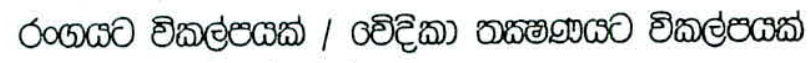 \\
\hline$*$ & 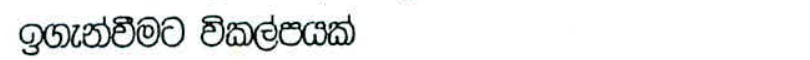 \\
\hline$*$ & 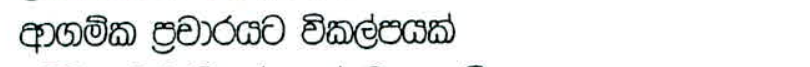 \\
\hline & 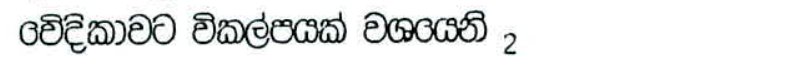 \\
\hline
\end{tabular}

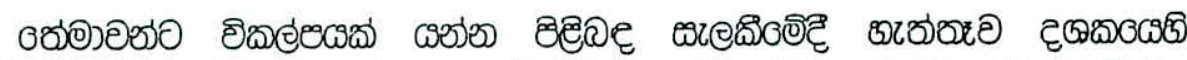

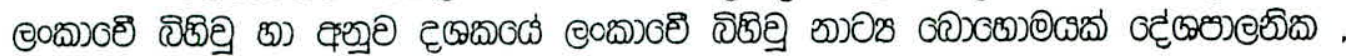

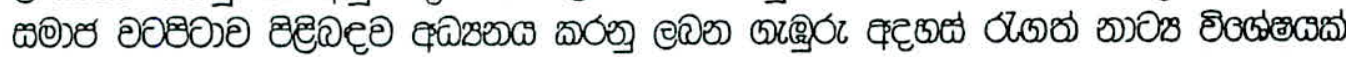

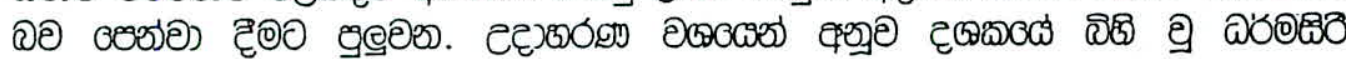

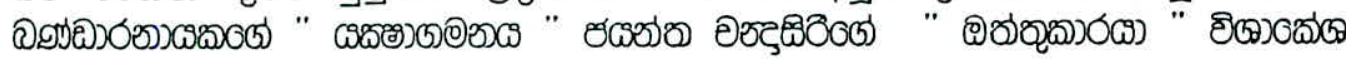

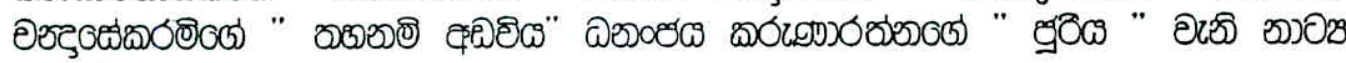

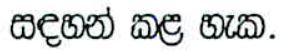

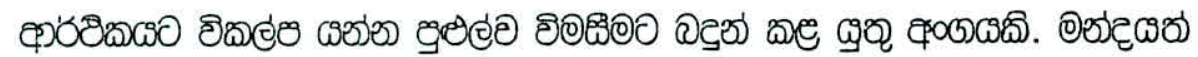

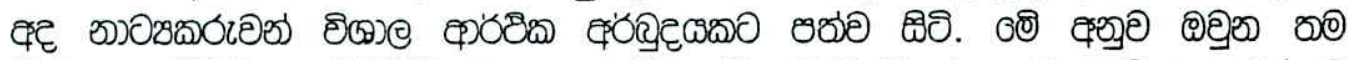

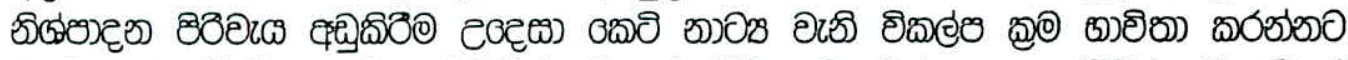

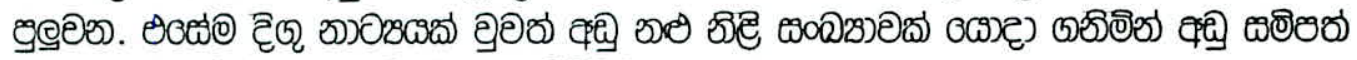

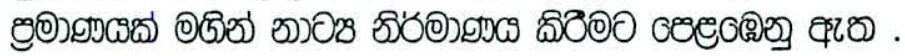

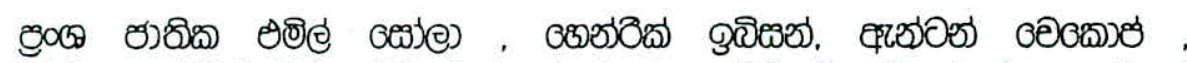

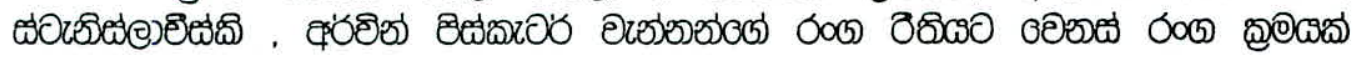

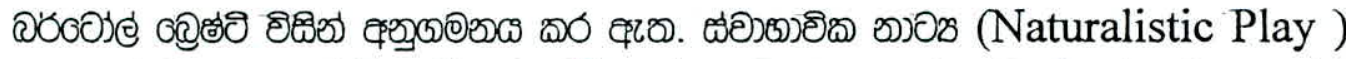

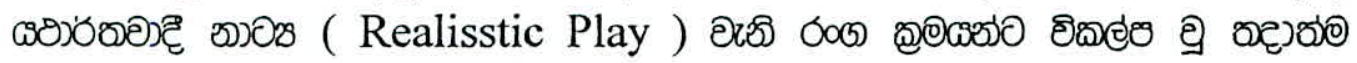

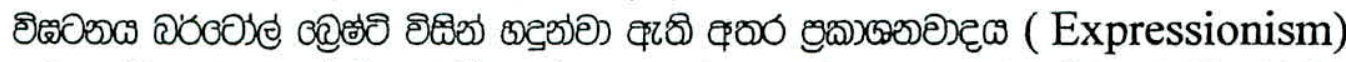

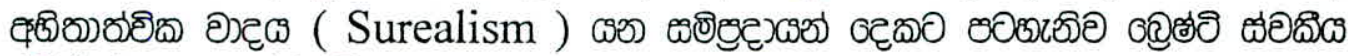

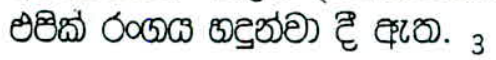

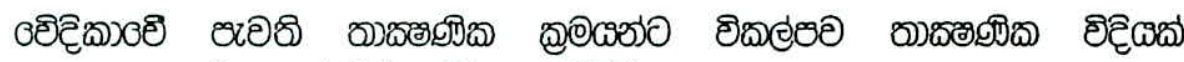

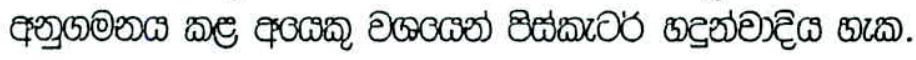

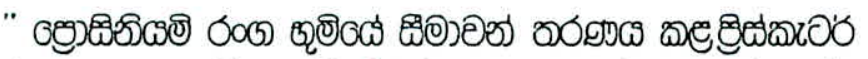

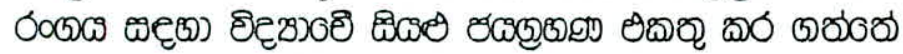

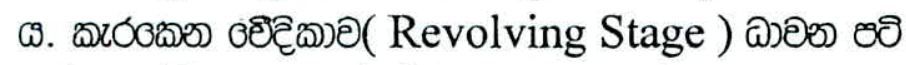

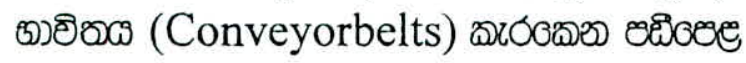




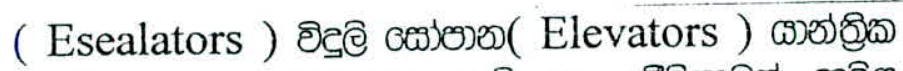

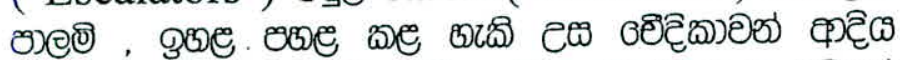

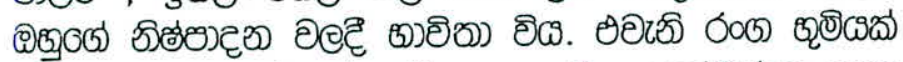

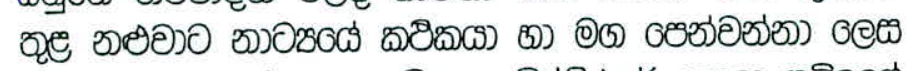

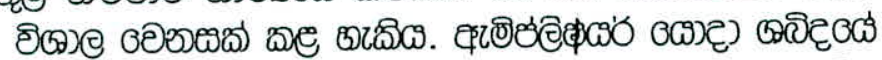

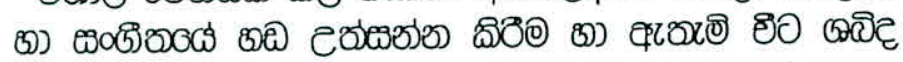

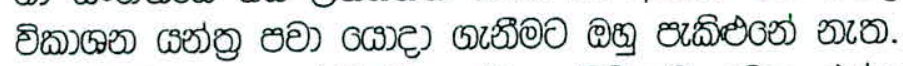

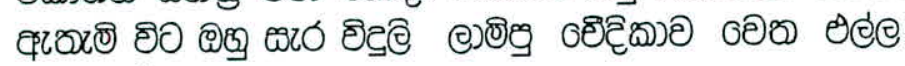
هGe

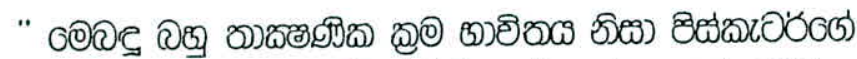

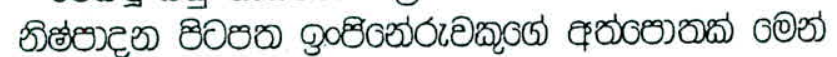

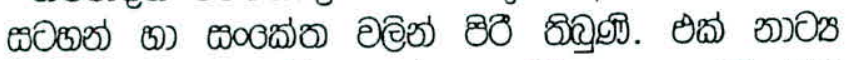

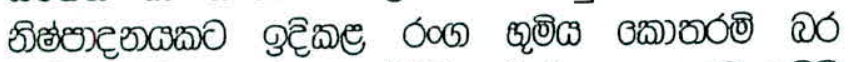

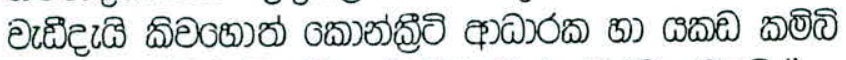

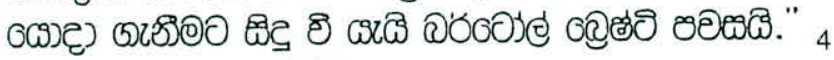

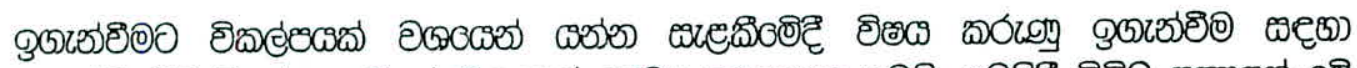
ఆ ఆ

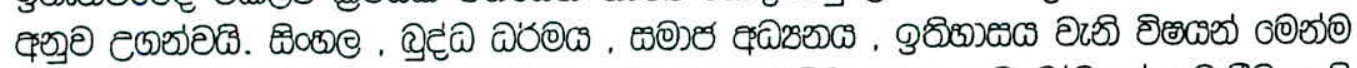

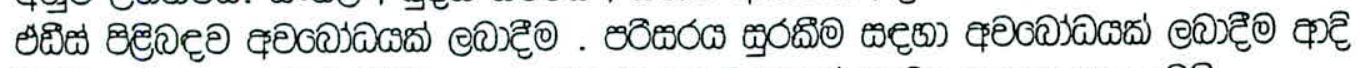

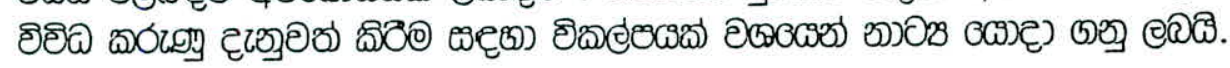

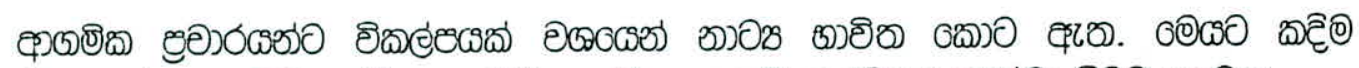

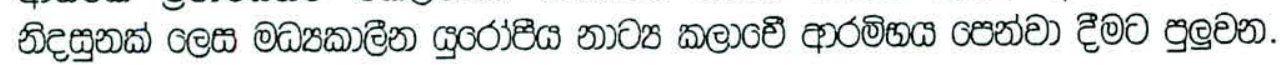

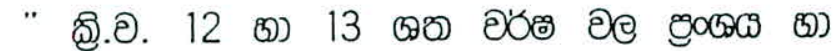

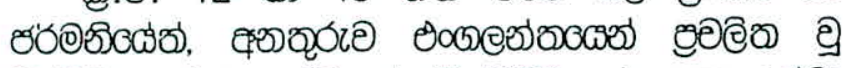

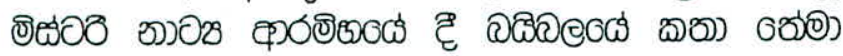

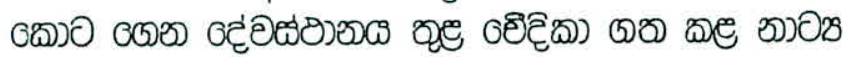

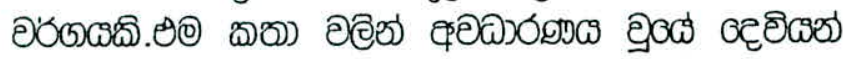
อఱ

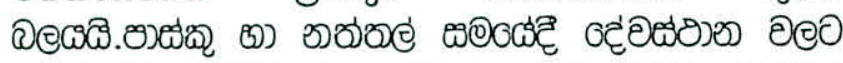

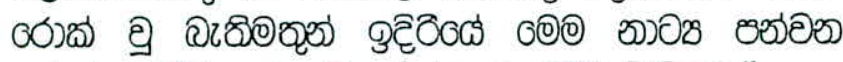

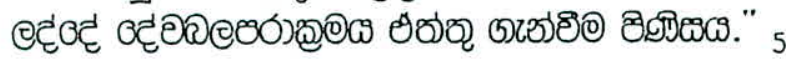

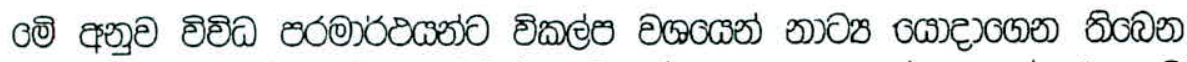

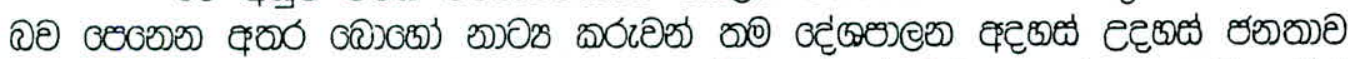

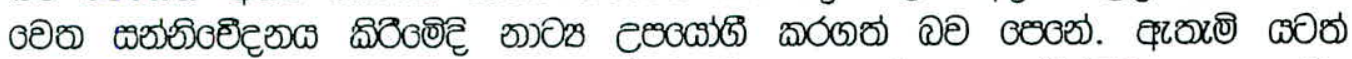

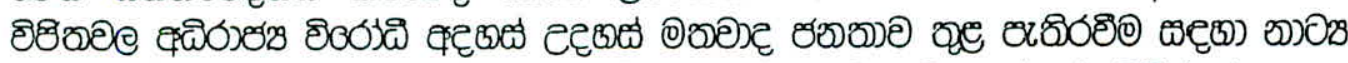

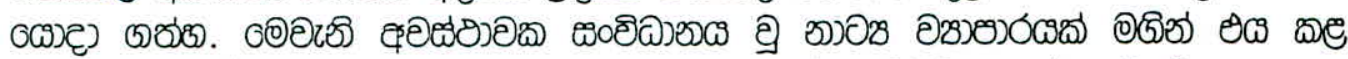
எ ర2)

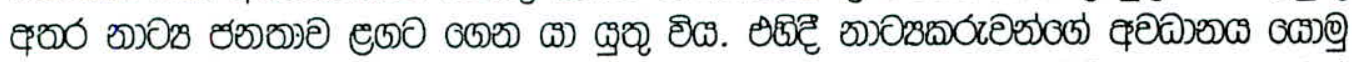

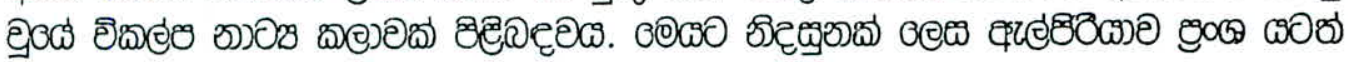

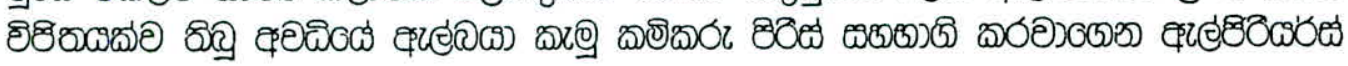




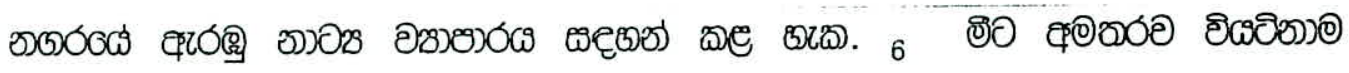

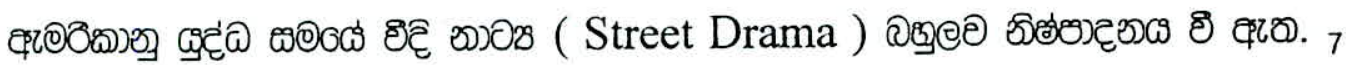

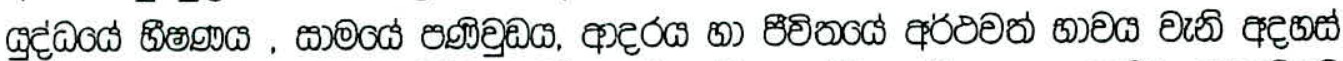

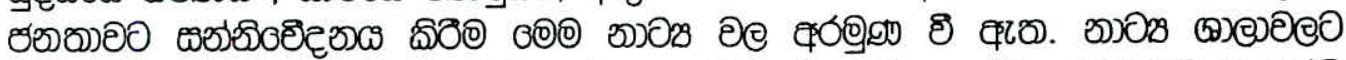

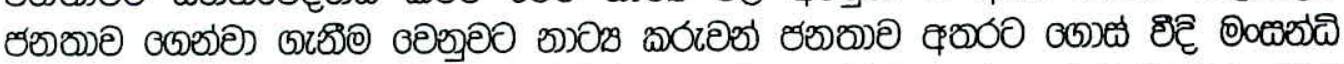

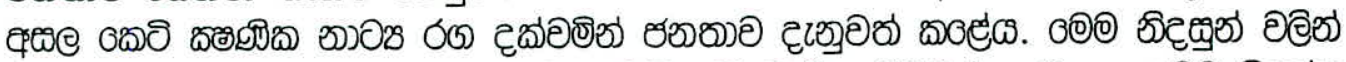

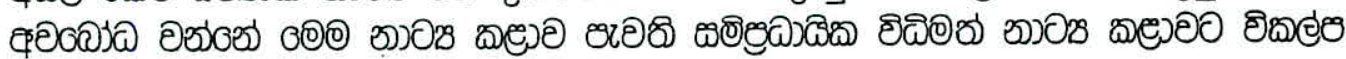

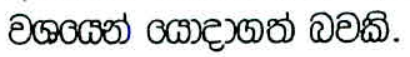

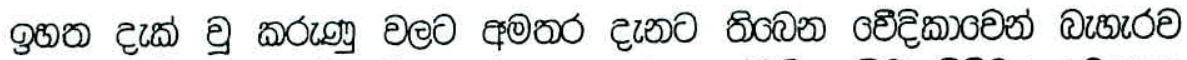

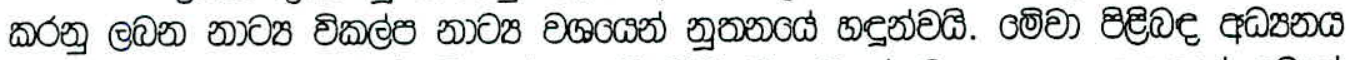

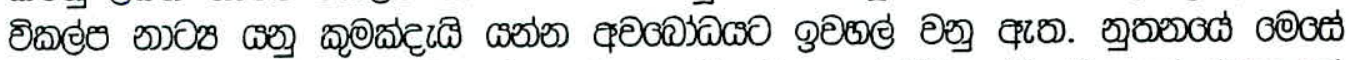

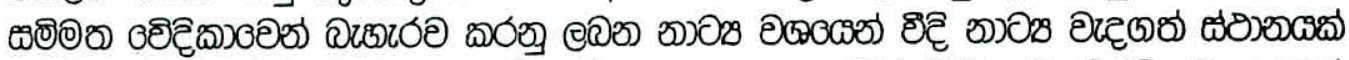

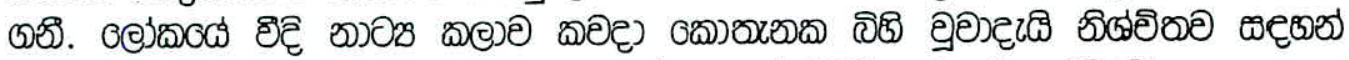

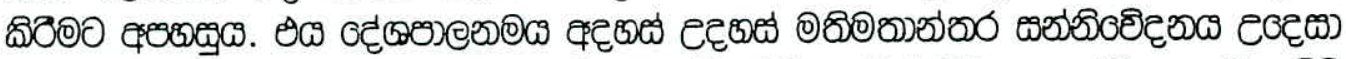

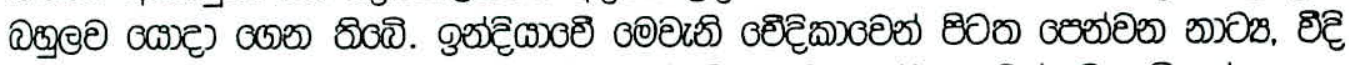

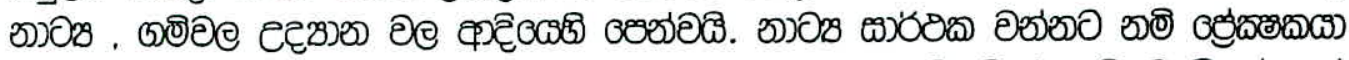

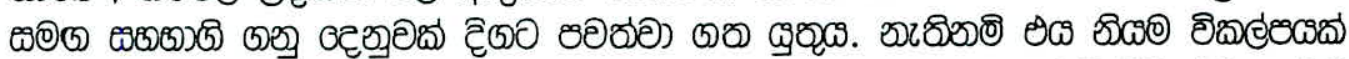

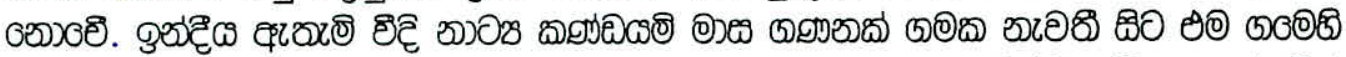
อน

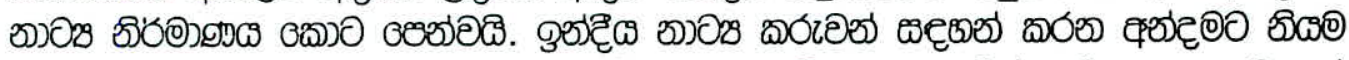

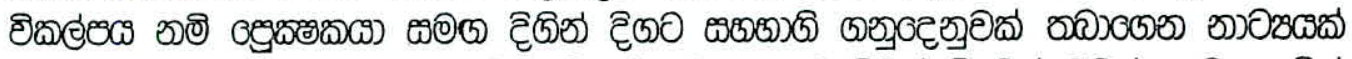
దகకరలెండి.

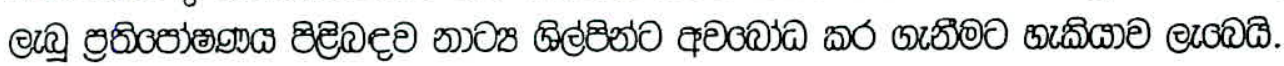

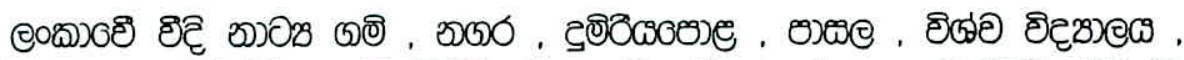

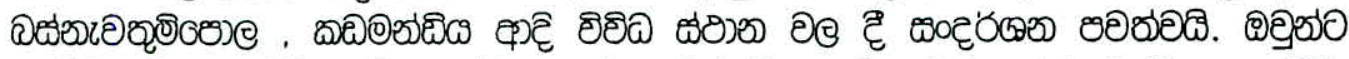

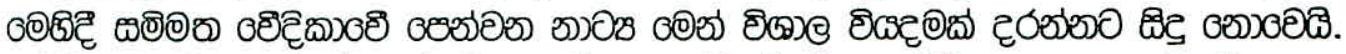

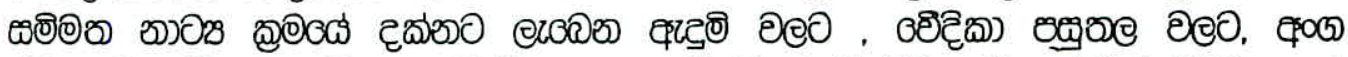

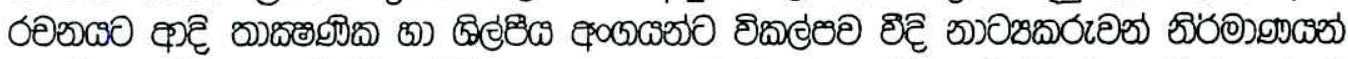

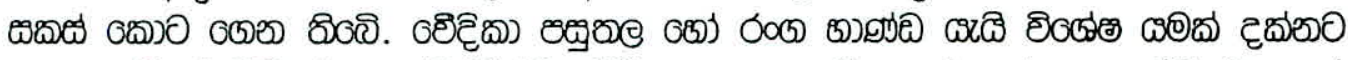

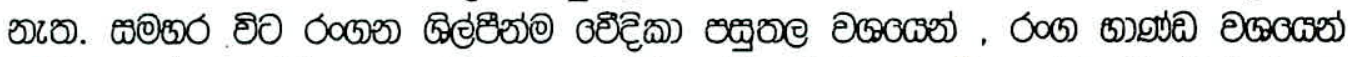

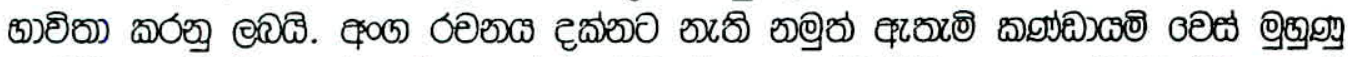

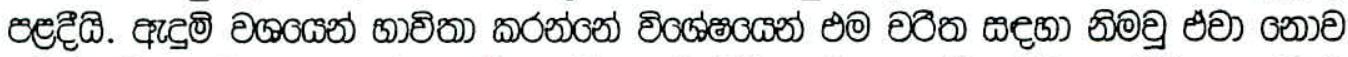

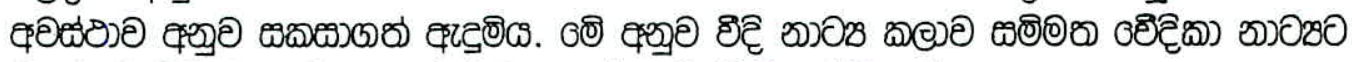

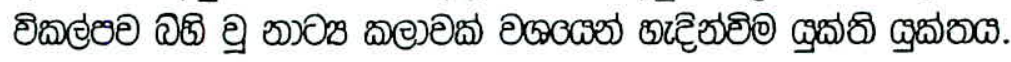

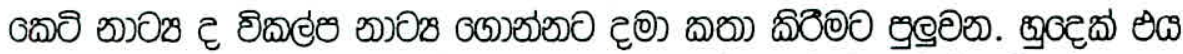

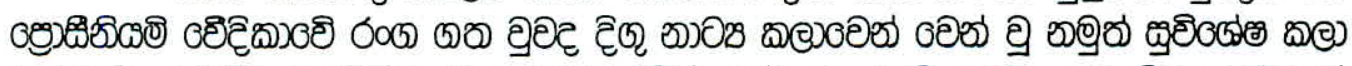

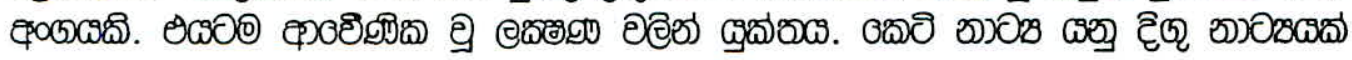

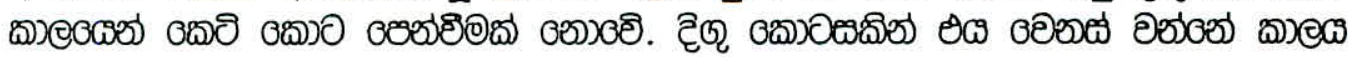

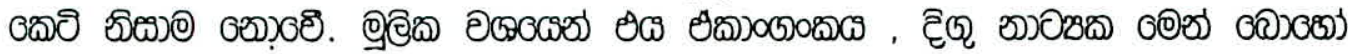

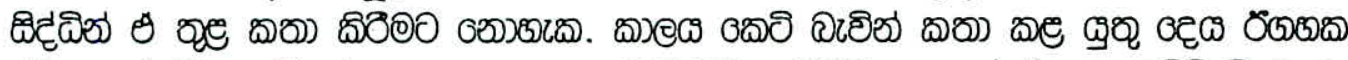

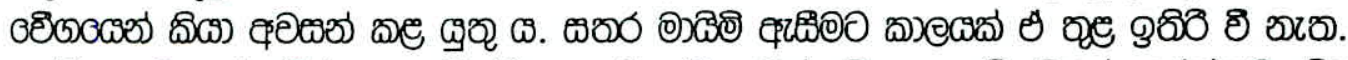

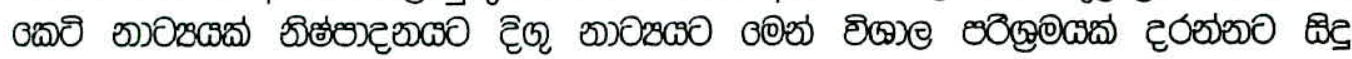




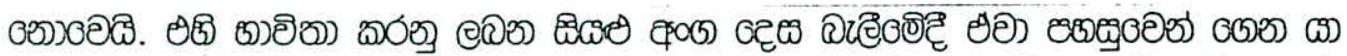

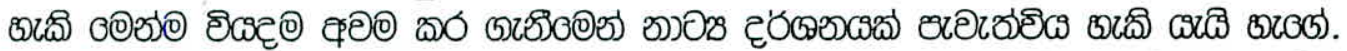

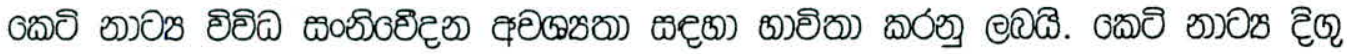

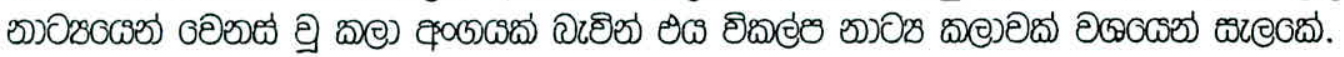

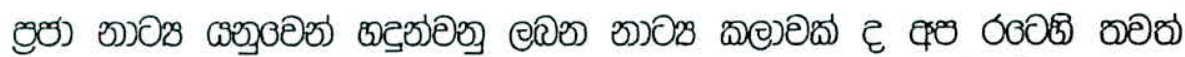

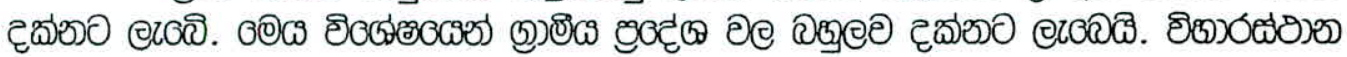

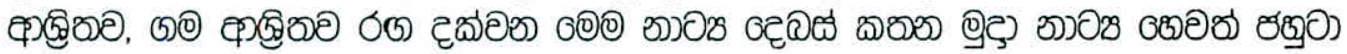

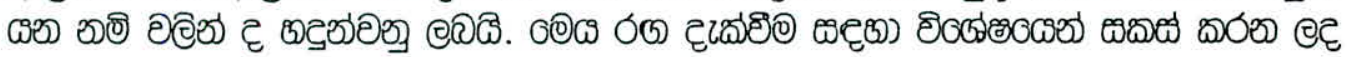

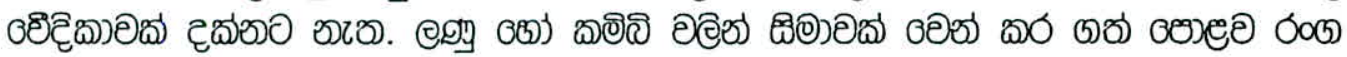

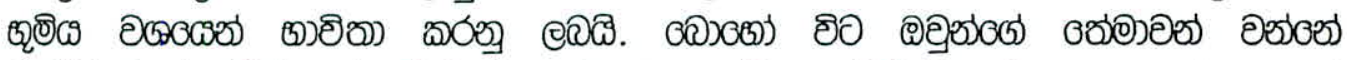

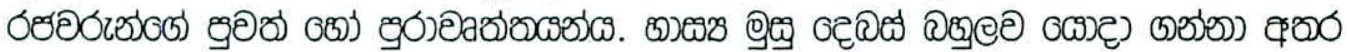

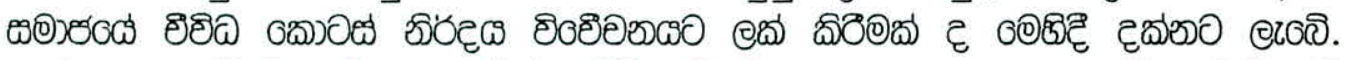

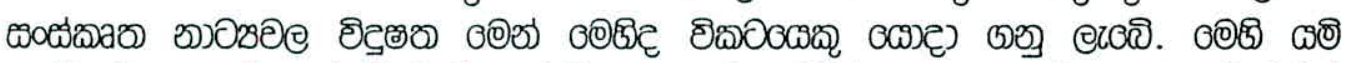

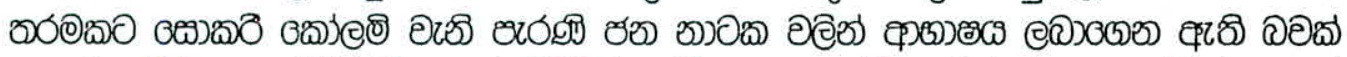

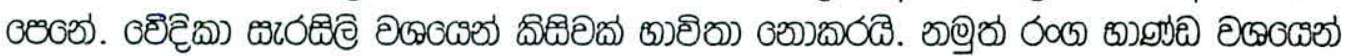

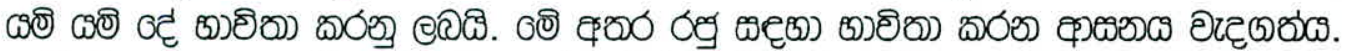

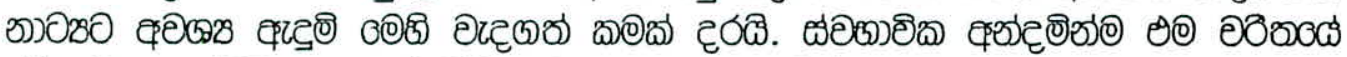

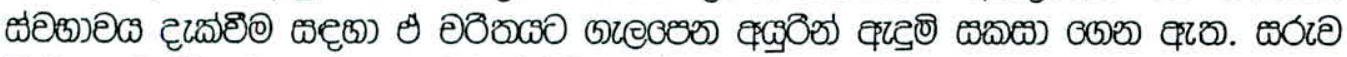

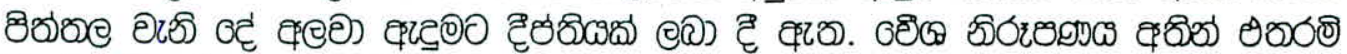

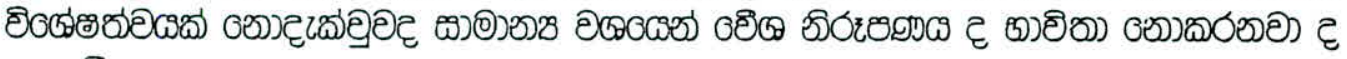
(8)) 10 .

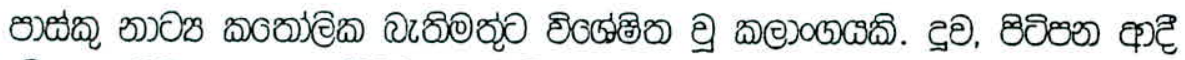

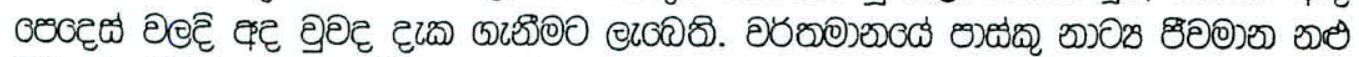

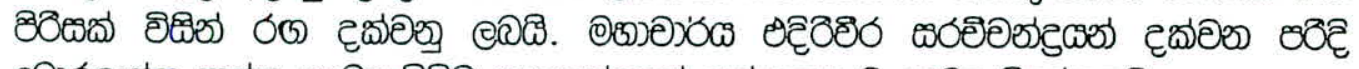

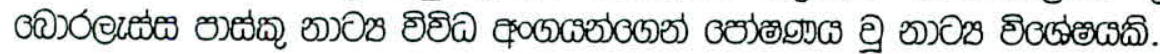

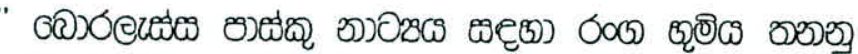

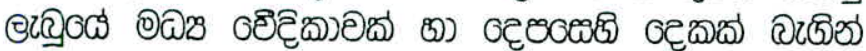

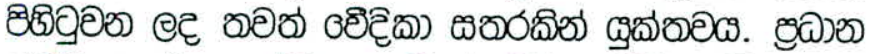

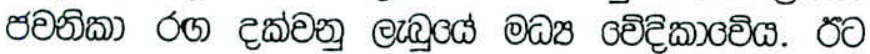

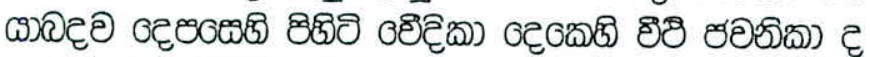

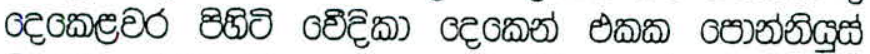

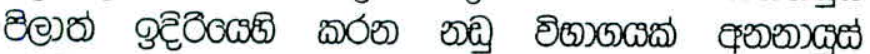

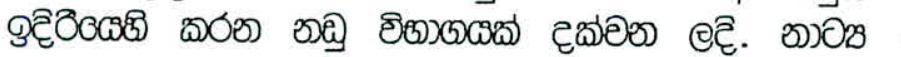

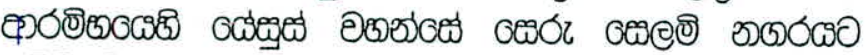

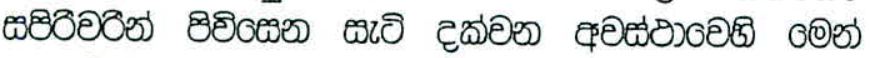

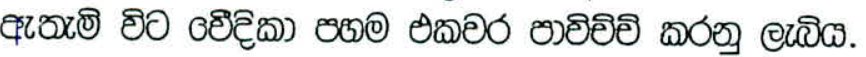

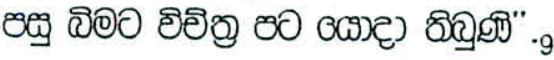

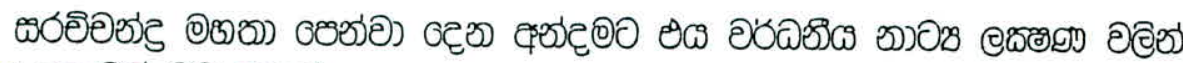

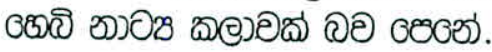




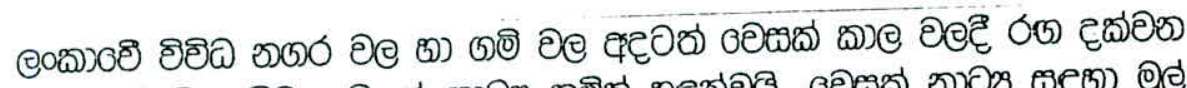

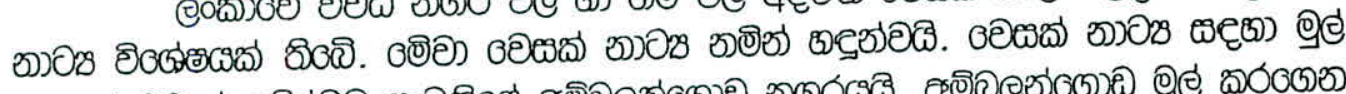

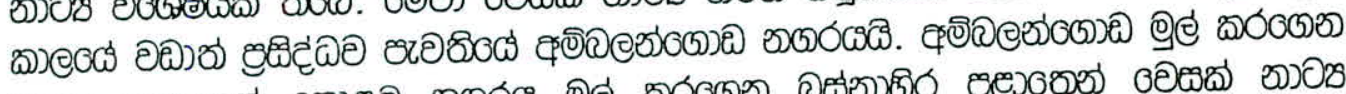

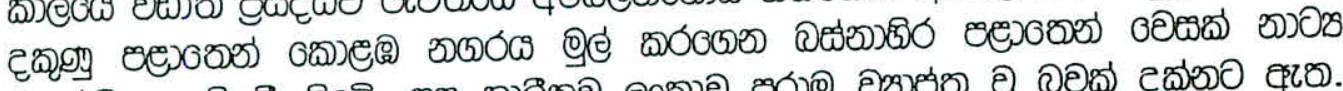

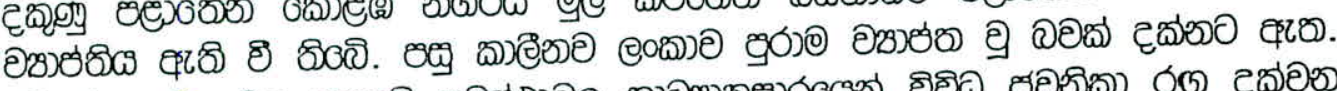

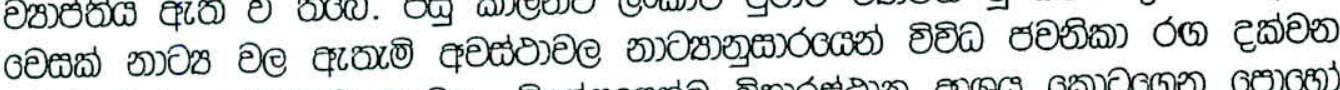

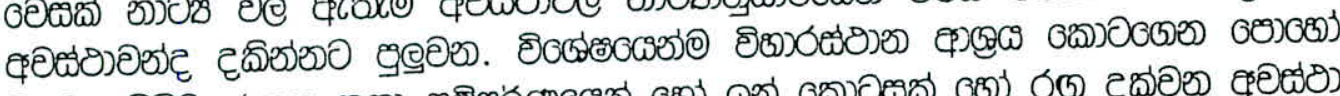

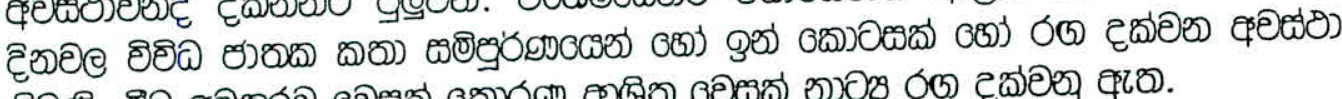

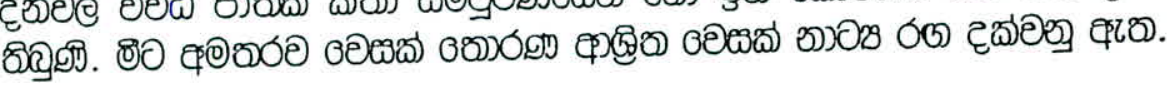

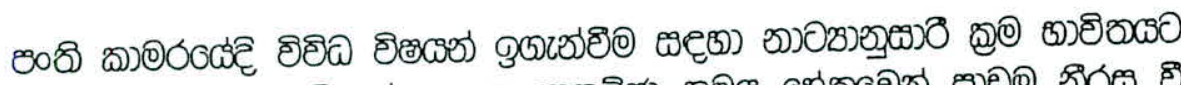
(53ో.

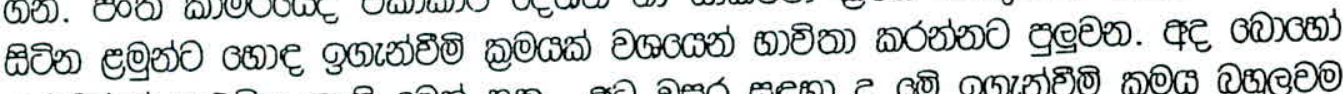

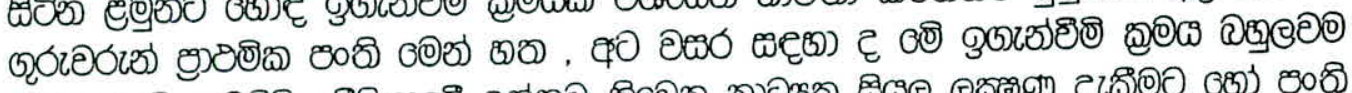

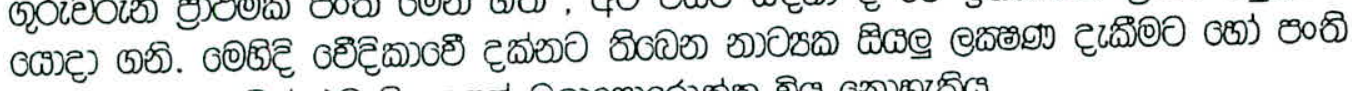

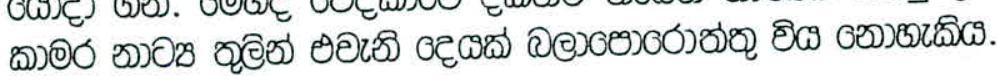

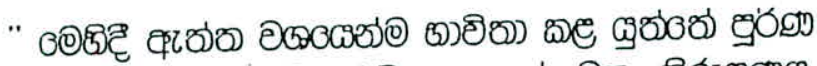
ग)

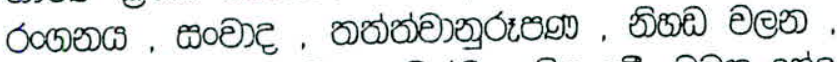

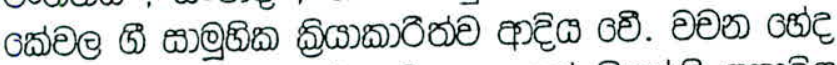
- gor

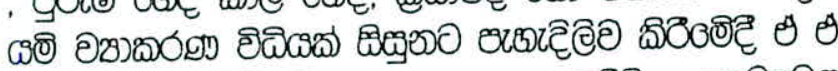

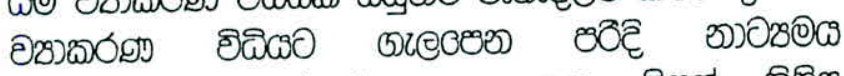

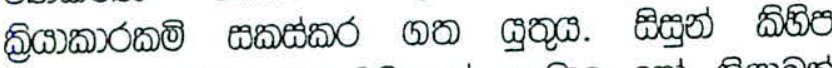

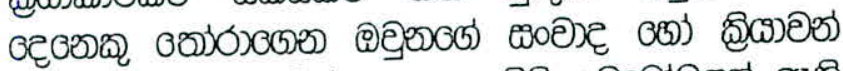

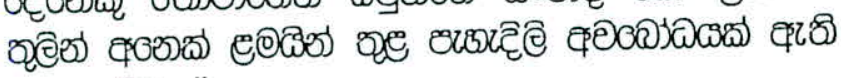

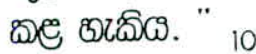

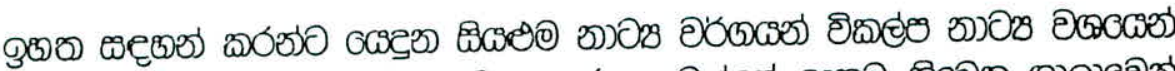

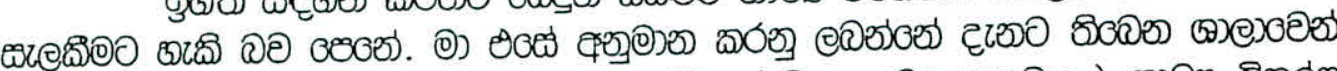

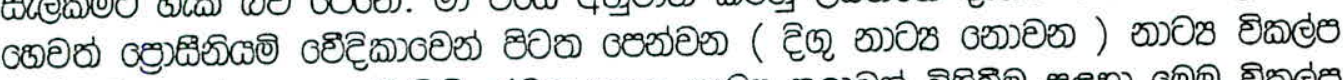

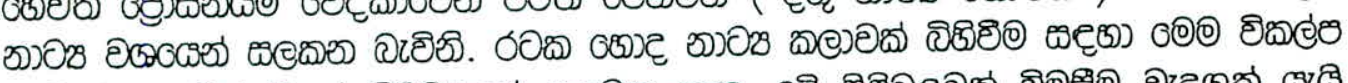

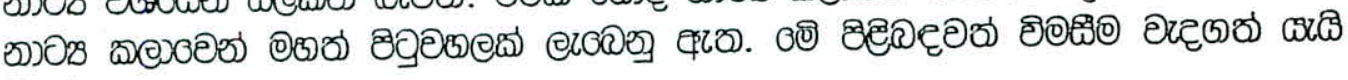

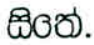

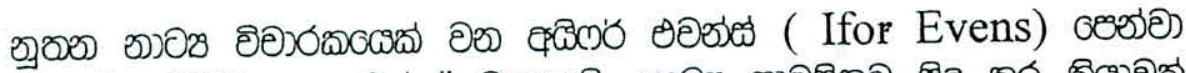

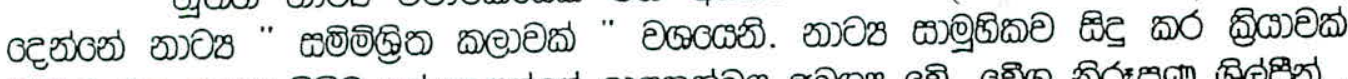

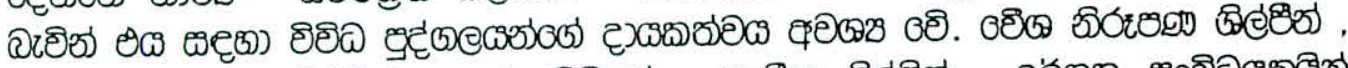

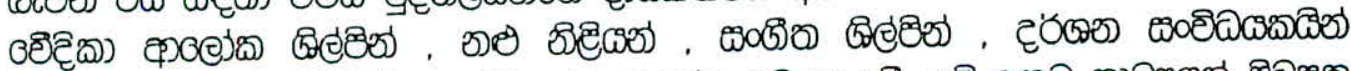

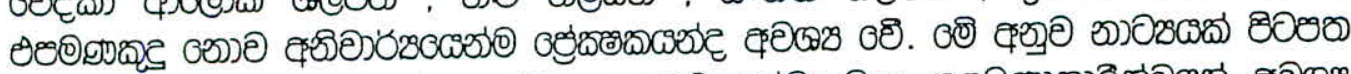

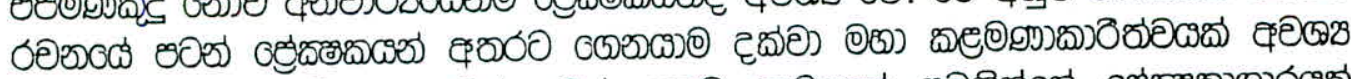

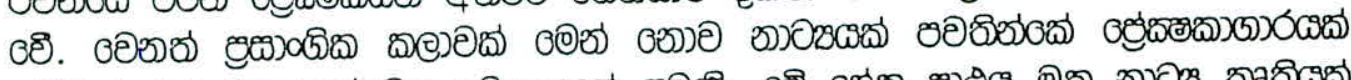

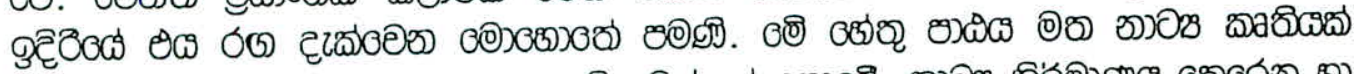

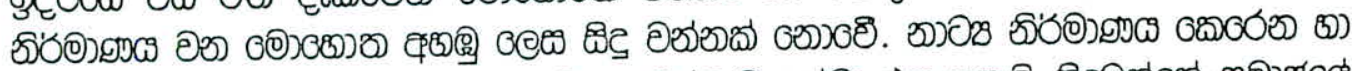

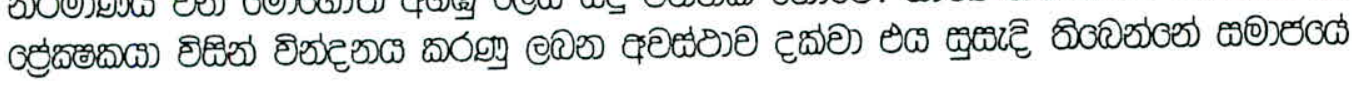

